\title{
PHARYNGEAL JAW STRUCTURE IN LABRID FISH
}

$\operatorname{AUTHOR}(S)$ :

Yamaoka, Kosaku

\section{CITATION:}

Yamaoka, Kosaku. PHARYNGEAL JAW STRUCTURE IN LABRID FISH.

PUBLICATIONS OF THE SETO MARINE BIOLOGICAL LABORATORY 1978, 24(4-6): 409-426

ISSUE DATE:

1978-10-15

URL:

http://hdl.handle.net/2433/175972

RIGHT: 


\title{
PHARYNGEAL JAW STRUGTURE IN LABRID FISH
}

\author{
Kosaku YAMAOKA \\ Department of Fisheries, Kyoto University, Kyoto
}

With Text-figures 1-9, Table 1 and Plate I

\begin{abstract}
The structure of the pharyngeal jaw in labrid fishes was examined. Materials examined as for the fourth levator externus, levator posterior and postpharyngeal ligament included 21 genera and 44 species. Relationships between degree of development of the pharyngeal jaw structure and feeding habit were discussed. These fishes were classified into seven types based on the structural pattern of levator posterior with existence of the supraoccipital crest in mind. The results obtained are shown as follows: 1) The fourth levator externus and levator posterior insert mainly on the lower pharyngeal bone and show a tendency to the independence of it as a feeding structure. 2) On the whole, the pharyngeal jaw structure is well-developed in hard-biting species which feed mainly on tough preys like molluscs and echinoids. 3) Each type of the levator posterior clearly corresponds to the feeding habit. The levator posterior plays an important role in feeding. 4) In Type PA, the supraoccipital crest serves as a site of insertion for the levator posterior. It also functions as a site of insertion for only the epaxial muscle in generalized percoid fishes and seems to be related to the body depth. 5) Mechanical differentiation of types was speculated.
\end{abstract}

\section{Introduction}

Labrid fishes are one of the commonest inhabitants in coral reef areas. They are, in general, carnivorous (Hiatt and Strasburg, 1960; Hashimoto, 1974) and all have the united lower pharyngeal bone functioning as a single unit, though they can be regarded to have various feeding habits within the range of carnivores. In cichlid fishes which also have the suturally united one, it has been observed that there was a close relationship between the degree of development of the lower pharyngeal bone and the feeding habit (Greenwood, 1965; Fryer and Iles, 1972; Liem, 1973). Furthermore, they are generally thought to have undergone the explosive adaptive radiation in the lacustrine habitat due to acquiring a special set of characteristics about pharyngeal jaw structure (Liem, 1973). But there have been few papers dealing with the biological significance of the pharyngeal jaw structure in labrid fishes in marine habitats. The purpose of this paper is to discuss the structure of the pharyngeal jaw of labrid fishes and to confirm its significance in exploiting the feeding habit by means of comparing with each other.

1) Contributions from the Seto Marine Biological Laboratory, No. 648.

Publ. Seto Mar. Biol. Lab., XXIV (4/6), 409-426, $1978 . \quad$ (Article 26) 


\section{Materials and Methods}

Most of labrid specimens examined in this study were collected in the Ryukyu Islands and deposited mainly at the Department of Fisheries, Kyoto University, Marine Ecological Researching Society of Kagoshima University and the Department of Biology, University of Ryukyus. Some specimens were taken from Oki Island, Shimane Prefecture. Some other specimens were supplied from the Seto Marine Biological Laboratory, Kyoto University. Names, sizes and numbers of the specimens examined are shown in Table 1, together with contents of the digestive tract of specimens of each species that are indispensable to analyze their feeding habits. For the osteological study, most specimens fixed in $10 \%$ formalin have been cleared with 4-7\% $\mathrm{KOH}$ solution and then stained with alizarin S. Glycerol has been used as a clearing agent. Dissections and most drawings in outline were made with a dissecting microscope and camera lucida attachment. The outlines of some figures were traced from photographs, and then details were added with freehand under a dissecting microscope. Observations of muscles and connective tissue elements (mainly ligaments) were made following Bock and Shear's method (1972). This technique should be adopted in the study of muscles of small fishes. Besides, it can be used to observe whitish organs, for example, brain and olfactory rosette, since they reflect the light and so cannot be observed in detail without this technique. The species names used in this paper followed Masuda et al. (1975). The osteological and myological nomenclatures were based on Liem (1973).

\section{Results}

A. Bone

1. Pharyngeal apophysis (Parasphenoid condyle)

The parasphenoid, situated at the basal part of the neurocranium, is an unpaired and elongate bone. A prominent process, i.e. pharyngeal apophysis, develops at the posterior part of this bone (Fig. 1). It forms the synovial joint between dorsal surface of the upper pharyngeal bones and basicranium. It shows considerable variety in labrid fishes mainly in its size (Fig. 2). In Macropharyngodon meleagris, Halichoeres poecilopterus and Pteragogus flagellifera, it is noticeably enlarged; that of Thalassoma cupido and Coris awayai follows the above group; in Labroides dimidiatus it develops only weakly. Meanwhile, $M$. meleagris has been reported to feed mainly on gastropods and coral polyps together with their calcareous bony elements (Hiatt and Strasburg, 1960; Hashimoto, 1974). H. poecilopterus and P. flagellifera are found to feed mainly on molluscs and relatively large crustaceans. The second group mainly on amphipods and other small crustaceans. L. dimidiatus has been reported to pick up ectoparasitic copepods and isopods from host fishes (Hiatt and Strasburg, 1960; Hashimoto, 1974). These facts suggest a certain relation between size of the pharyngeal apophysis and feeding habit. 


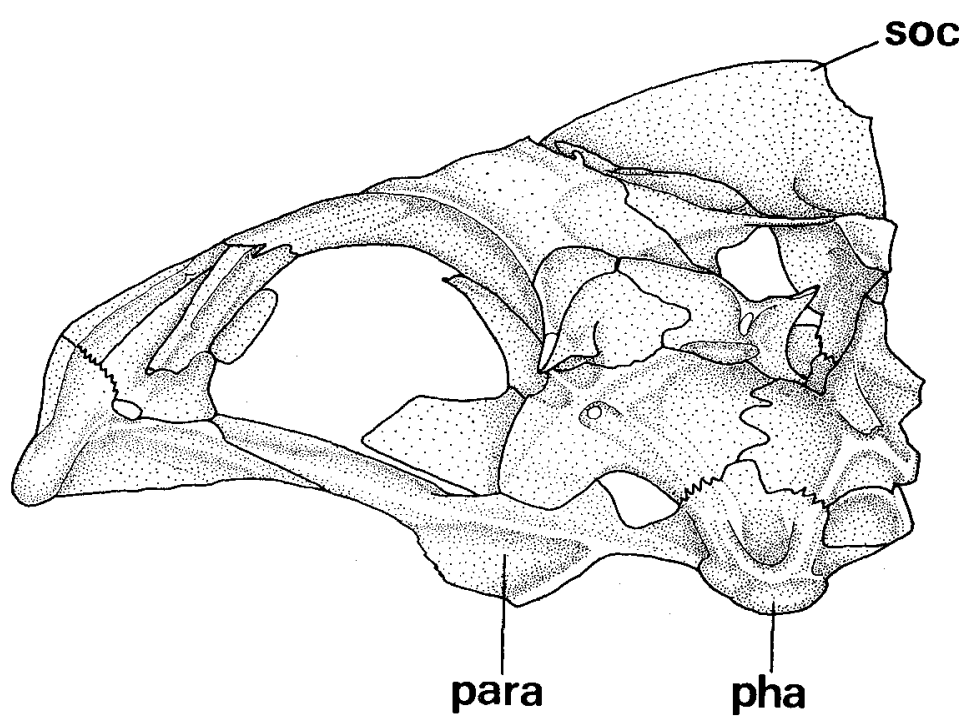

Fig. 1. Lateral view of neurocranium of Pteragogus flagellifera. para, parasphenoid; pha, pharyngeal apophysis; soc, supraoccipital crest.

\section{Epibranchial}

There are four pairs of epibranchials dorsal to the ceratobranchials. On each body side, these bones are connected with each other by the minute ligaments or directly. The third and fourth ones have synovial joints with the dorsolateral surface of the upper pharyngeal bone. The latter is complex in form and functions as a site of insertion mainly for the levator posterior. In $M$. meleagris and $P$. flagellifera, the fourth one is the largest. On the other hand, in T. cupido, T. amblycephala, T. lunare, Coris awayai and L. dimidiatus, the first one is the largest (Fig. 3). Therefore, development of the fourth one correlates with that of the levator posterior.

\section{Infrapharyngobranchial}

Nelson (1967) suggests that in some labrid fishes, the first infrapharyngobranchial becomes cartilaginous or absent, the second one has no teeth and the third one is fused with fourth one, which forms the upper pharyngeal bone. The author can find no calcified first one in all species examined. The second one is a small and curved bone situated just anterior to the upper pharyngeal bone. The second one is inversely proportional in size to that of the upper pharyngeal bone and the fourth epibranchial (Fig. 3).

4. Lower pharyngeal bone and teeth

Roughly speaking, the lower pharyngeal bone is composed of an anterior blade and a couple of muscular processes projecting posterolaterally. Except Labroides dimidiatus, Labropsis manabei and Labrichthys unilineata, the dorsal surface of the lateral tip of the muscular process is the site of insertion for the fourth levator externus and levator posterior. In general, on the dorsal surface except just above-mentioned site of insertion, there are many pharyngeal teeth. The pharyngeal teeth situated 

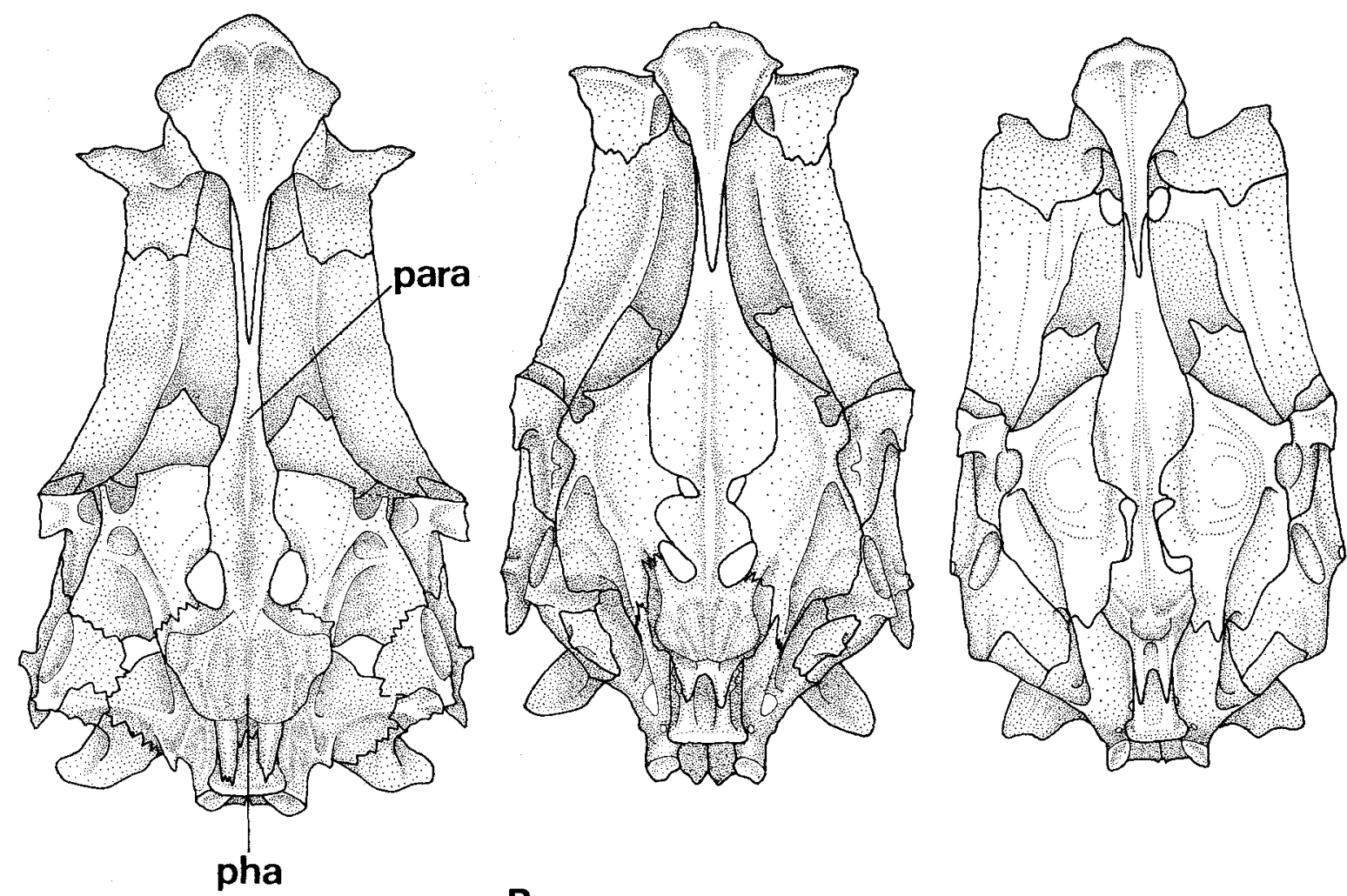

年

A

B

C

Fig. 2. Ventral view of neurocranium of Pteragogus flagellifera (A), Thalassoma cupido (B) and Labroides dimidiatus (C). Symbols are same as in Fig. 1. 


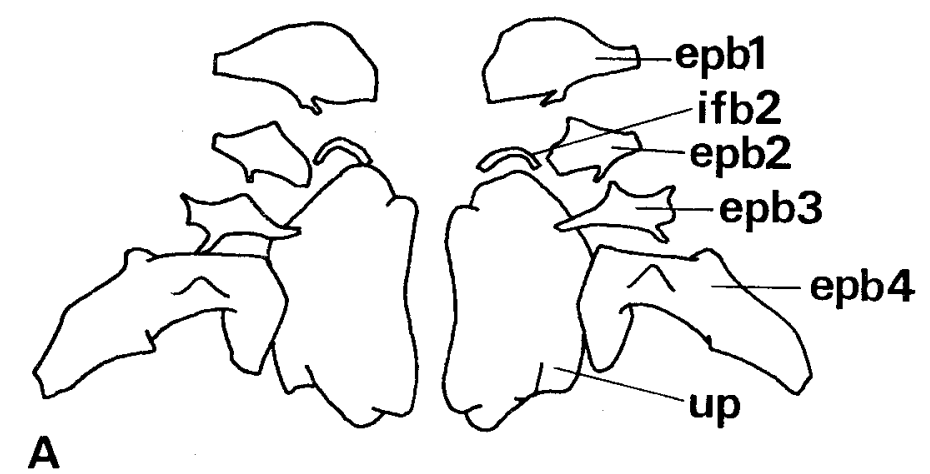

B

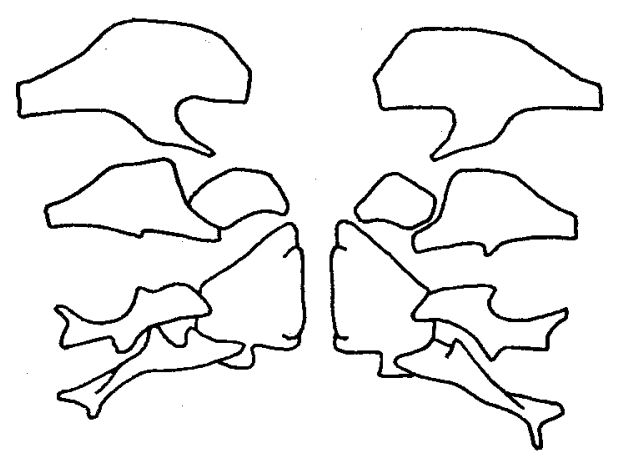

C

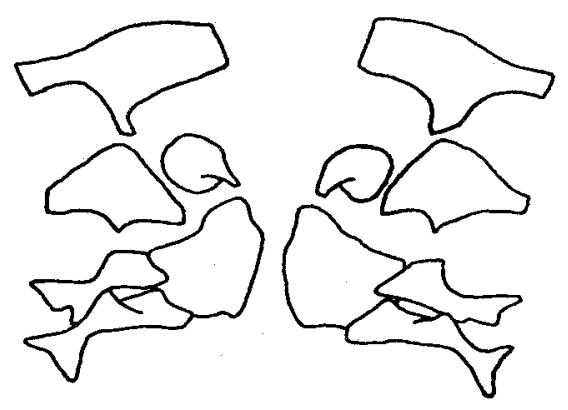

D

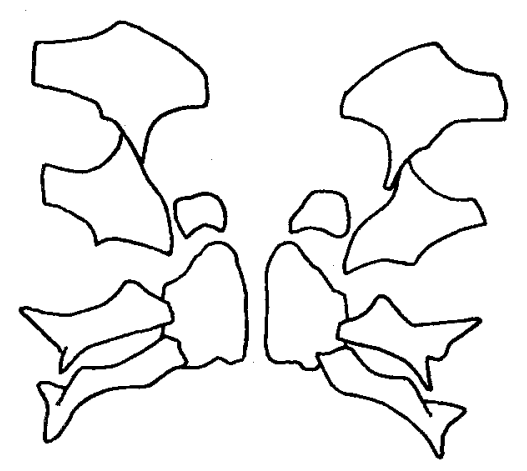

Fig. 3. Dorsal view of upper pharyngeal arch of Macropharyngodon meleagris (A), Coris awayai (B), Thalassoma amblycephala (C) and Labroides dimidiatus (D). epb, epibranchials; ifb, infrapharyngobranchial; up, upper pharyngeal bone. 
posteriorly are larger and among them the median tooth is the largest. Development of the lower pharyngeal bone and teeth roughly corresponds to that of the levator posterior. The species, having well developed, is provided with a very stout and large lower pharyngeal bone and teeth. As a matter of course, a variety of these structures can be seen. For example, Cheilio inermis shows weaker development of these structures, considering its good development of the levator posterior. This may be related to the fact that $C$. inermis feeds mainly on sponges (Hashimoto, 1974). Two types of the pharyngeal teeth can be distinguished among the species whose levator posterior develop very well. One is shown in Halichoeres centiquadrus, $H$. trimaculatus, $H$. poecilopterus, Coris gaimardi and $M$. meleagris (Pl. IA, B). A large molar-like tooth appears on the posteromedial part of dorsal surface of the lower pharyngeal bone. Laterally situated teeth are usually a little finer. Particularly in $M$. meleagris, this trend reaches the maximum point of development in this type. There is almost only a posteromedial molar-like tooth. The other type is shown in Bodianus perditio, B. loxozonus, Choerodon anchorago and C. azurio (Pl. IC, D). Many small and low teeth are aggregated densely on the dorsal surface and form a wide dental plate. But even in this type the posteromedial teeth have the tendency to be relatively enlarged. These two types are regarded as the most appropriate adaptation for crushing tough preys. One can see weaker situations than those shown in above-mentioned two groups, in species whose levator posterior develop well (Pl. IE, F). Among the species whose levator posterior develop weakly, large ones like Hemigymnus fasciatus and H. melapterus have a molar-like tooth on posteromedial surface but generally that tooth becomes conical (Pl. IG, H). Among the species whose levator posterior develop only very weakly, those of $L$. unilineata become conical as shown by Randall and Springer (1973). In L. dimidiatus, conical teeth increase in number. This pattern of dentition do not adapt for crushing tough preys, but for transporting food into the esophagus.

5. Upper pharyngeal bone and teeth

The upper pharyngeal bone can be thought to be composed of the third and fourth infrapharyngobranchials and, in general, has many teeth on the ventral surface. Medial teeth are larger than lateral ones. The dorsal surface forms the basipharyngeal joint with pharyngeal apophysis of the neurocranium. The first and second levator interni have sites of insertion on the anterodorsal part and the retractor pharyngeus superior on the posterior part. The synovial joints are formed with the third and fourth epibranchials on the dorsolateral part. The upper pharyngeal bone and teeth show the same trend as the lower ones.

B. Muscle

1. Levator externus 4

The fourth levator externus is at the posteromost part of the levator externi series and develops very well as compared with other muscles of this series (Fig. 4). Except L. dimidiatus, L. manabei and L. unilineata, in all species examined, the greater parts bypass the fourth epibranchial and muscle fibers change into a stout 


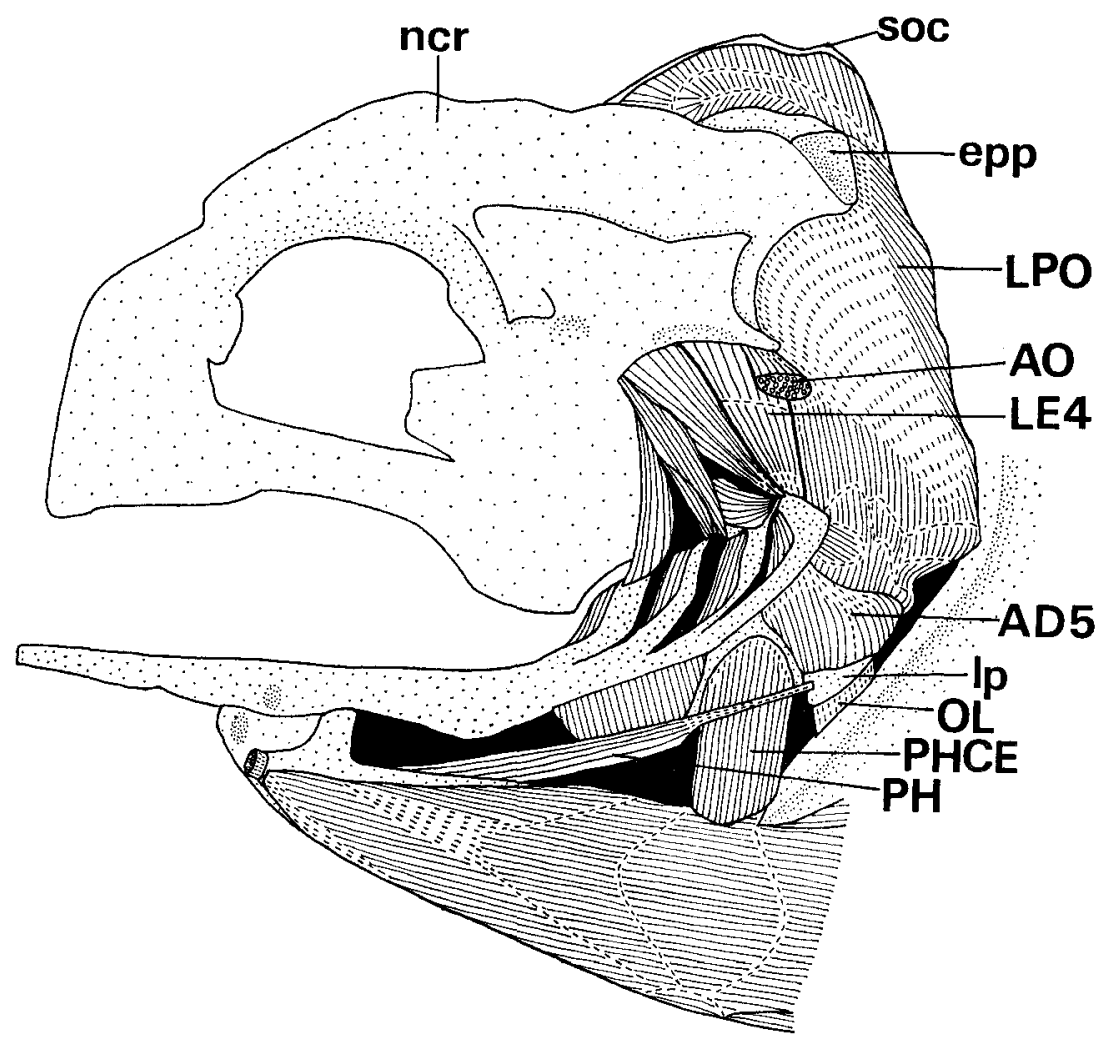

Fig. 4. Lateral view of branchial and pharyngeal region of Halichoeres poecilopterus. Opercular, suspensory, jaw and hyoid apparatus, gill and mucous membrane removed. AD5, fifth adductor; AO, adductor operculi; LE4, fourth levator externus; LPO, levator posterior; PH, pharyngohyoideus; PHCE, pharyngocleithralis externus; epp, epiotic process; lp, lower pharyngeal bone; ncr, neurocranium; OL, postpharyngeal ligament. Other symbols are same as in Fig. 1.

tendon, though there are some muscle fibers inserting the fourth epibranchial. This tendon fuses with that of the levator posterior (Fig. 5). It inserts laterodorsal surface of the muscular process of the lower pharyngeal bone. The origin is musculous. Superficially it can be distinguished from the levator posterior distinctly. According to Winterbottom (1974), the levator externi mucsles usually connect the neurocranium to the epibranchials in teleosts. But the structure in labrid fishes except above-mentioned three species does not conform to this definition. This structural pattern can be considered to elongate its muscle bundle as a result of shift of the site of insertion ventrally to the muscular process of the lower pharyngeal bone. So the force exerted by contraction of the muscle bundle becomes greater. While, above-mentioned three species have their sites of insertion of the fourth levator externus, together with the levator posterior, on the fourth epibranchial. They have no direct contact with the lower pharyngeal bone (Fig. 6). This specialized pattern in three exceptional species also has relation to the fact that they feed mainly on small ectoparasitic crustaceans or coral polyps (Table 1). These preys do not demand a powerful adduction (or occlusion) by both pharyngeal bones. Pharyngeal bones 


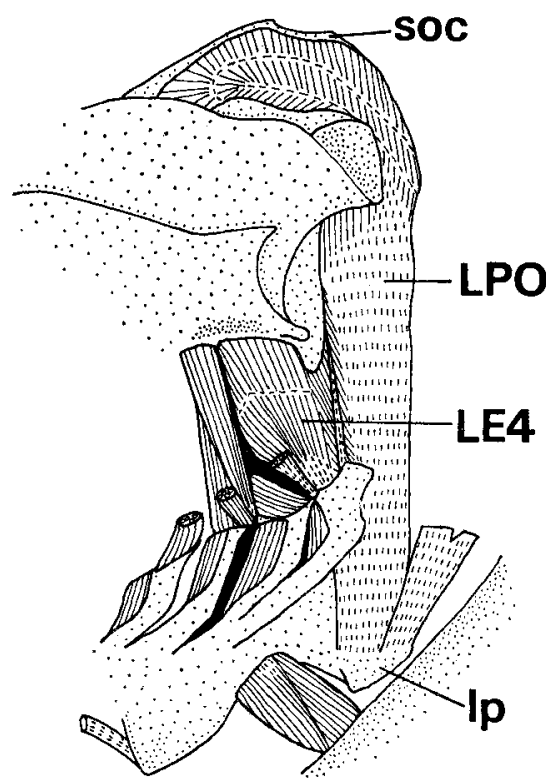

Fig. 5. Lateral view of branchial and pharyngeal region of $H$. poecilopterus. In addition to Fig. 4, superficial muscle fibers of levator posterior, fifth adductor, pharyngocleithralis externus and postpharyngeal ligament removed. Symbols are same as in Fig. 4.

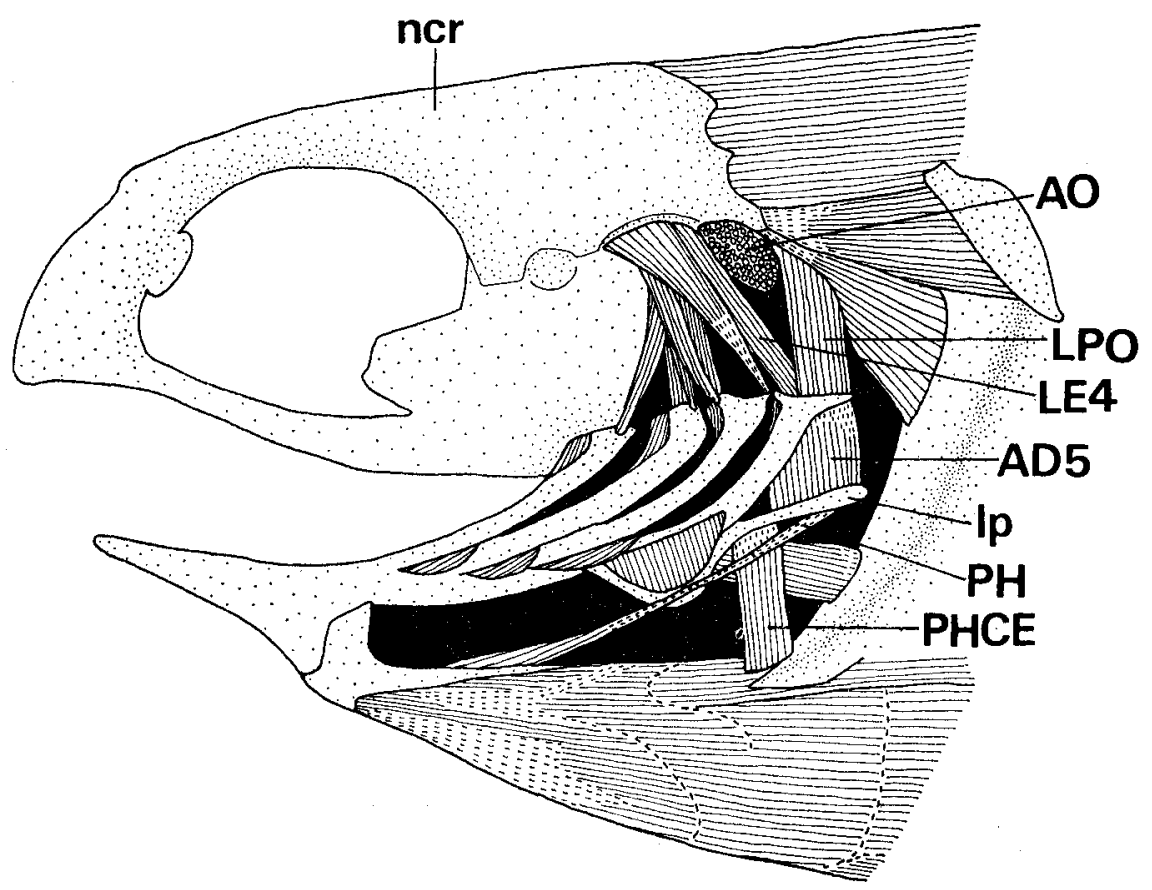

Fig. 6. Lateral view of branchial and pharyngeal region of L. dimidiatus. Opercular, suspensory, jaw and hyoid apparatus removed. Symbols are same as in Fig. 4. 
transport the prey into the esophagus.

\section{Levator posterior}

Except L. dimidiatus, L. manabei and L. unilineata, the levator posterior is a well developed muscle posterior to the fourth levator externus (Fig. 4). In general, insertion is on the fourth epibranchial and the lower pharyngeal bone. The situation on the former is externally musculous but internally tendinous partially. On the latter, muscle fibers insert externally but internally develops a stout tendon. This tendon stretches dorsally within the muscle fibers (Fig. 5). The muscle bundle of the latter is thicker than that of the former. According to Winterbottom (1974), in teleosts, the levator posterior originates from the ventral or lateral surface of one or more of the following bones: pterotic, epiotic, intercalar and exoccipital. But the site of origin varies in labrid fishes. In many species, for example, $M$. meleagris, Choerodon azurio, Bodianus perditio, $H$. poecilopterus and Coris gaimardi, the supraoccipital crest is included in the origin. This specialization is unique among teleosts. It is concerned with feeding habit of these species which demands powerful adduction of the lower pharyngeal bone to crush a tough prey. In M. meleagris, in addition to the supraoccipital crest, even a part of the posttemporal fossa is included in the site of origin. Meanwhile, in species demanding not so powerful adduction, the dorsal tip of it shifts ventrolaterally toward the epiotic process. The more ventrolaterally the origin shifts on the neurocranium, the thinner this muscle bundle becomes. Furthermore, the cleithrum also fulfills a role for insertion at least in Cheilinus chlorurus and Bodianus loxozonus. Since the muscle direction is at the optimum angle, i.e. almost perpendicular to the body axis, the power exerted by the contraction of it is transmitted effectively. In $L$. dimidiatus, $L$. manabei and $L$. unilineata, it, like the fourth levator externus, inserts the fourth epibranchial alone (Fig. 6). It can be interpreted that this structural change is the same as that of the fourth levator externus.

3. Retractor pharyngeus superior

The retractor pharyngeus superior develops well in labrid fishes generally $(H$. poecilopterus, Thalassoma hardwicke, Bodianus loxozonus, $M$. meleagris and L. dimidiatus).

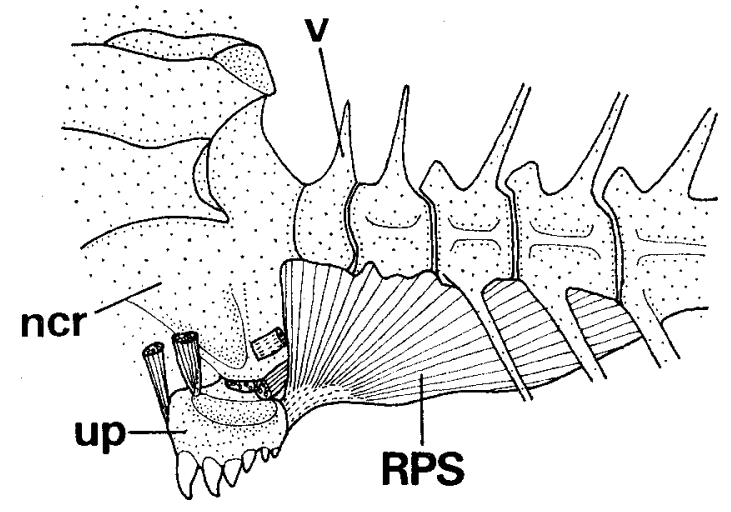

Fig. 7. Lateral view of retractor pharyngeus superior of $H$. poecilopterus. RPS, retractor pharyngeus superior; v, vertebra. Other symbols are same as in Figs. 3 and 4. 
It is situated posterodorsally to the upper pharyngeal bones (Fig. 7). This muscle can be divided into two, left and right muscle bundles. The first four species show the same degree of development. That is, the posterior end of this muscle originates from a medial surface of the ventral part of the fifth vertebra with weak tendon. Except this place, the origin is musculous. In L. dimidiatus, posterior end of it reaches only the fourth vertebra. The structural pattern that posterior end reaches the fifth vertebra seems to be general in labrid fishes. The specialized structural pattern in L. dimidiatus corresponds to its characteristic feeding habit and can be considered as a secondary specialization.

4. Pharyngohyoideus

In all species examined, the pharyngohyoideus is a weakly developed muscle (Figs. 4 and 6). It extends between dorsal margin of the urohyal and ventrolateral part of the muscular process of the lower pharyngeal bone. It becomes a slender tendon where it crosses the surface of the pharyngocleithralis externus. On the other hand, the attachment to the urohyal is musculous. It is conceivable that this slender tendon was brought by frictions caused by vigorous activity of this muscle and pharyngocleithralis externus.

\section{Ligament}

1. Postpharyngeal ligament

The postpharyngeal ligament is short and connects the posteroventral part of the muscular process of the lower pharyngeal bone with the cleithrum (Fig. 4). Development of this ligament is in proportion to that of the levator posterior. In L. dimidiatus, L. manabei and $L$. unilineata, it is only weakly developed and becomes membraneous.

\section{Discussion}

Liem (1973) has demonstrated that all cichlid fishes exhibit the following three specialized morphological patterns: 1) appearance of synovial basipharyngeal joint, 2) sutural connection of the two fifths ceratobranchials to form a single lower pharyngeal bone provided with a pair of muscular processes and 3) shift of insertion of the fourth levator externus from the fourth epibranchial to the lower pharyngeal bone. By virtue of these three specializations, cichlid fishes have been able to prepare and manipulate foods. In the species which feed mainly on tough preys, they develop better than ones feeding on soft preys. Extraordinary success in adaptive radiation with respect to the exploitation of new habitats has been due to the fact that the mandibular and premaxillary jaw mechanisms have been freed from their dual tasks of food collection and preparation by eliminating the latter function. Among these three specializations, the third one is proposed to be the crucial primary morphological innovation. They generally can be seen in labrid fishes too, with a few exceptions.

When it comes to the levator posterior, some cichlid fishes exhibit the same pattern as that of most species of labrid fishes. It originates from the neurocranium just 

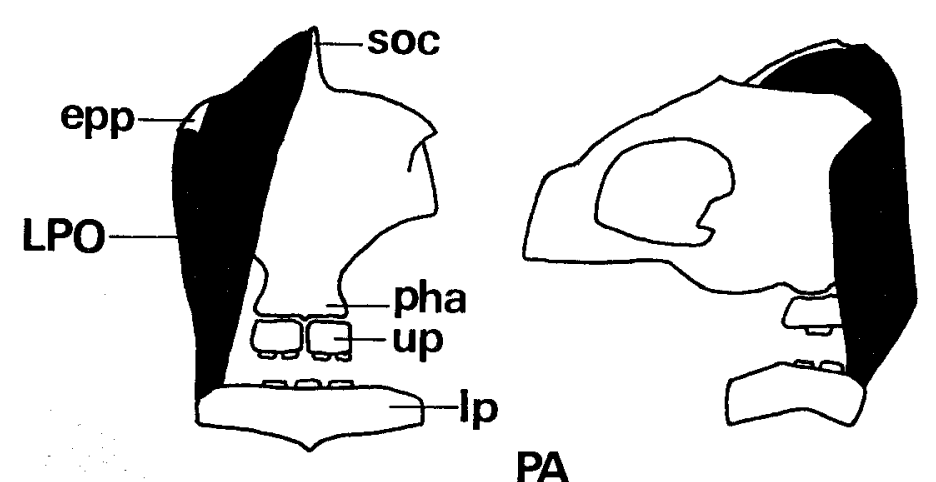

PA

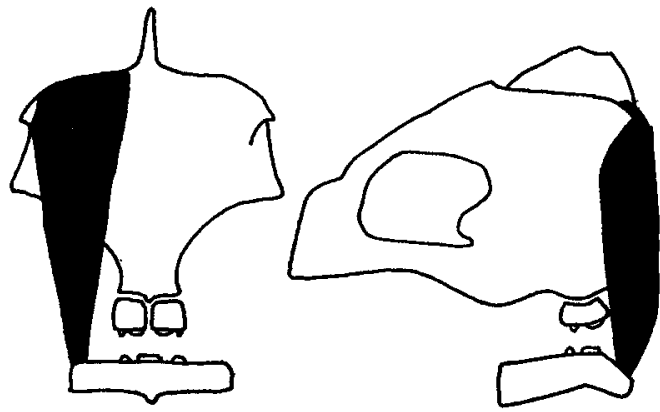

PB

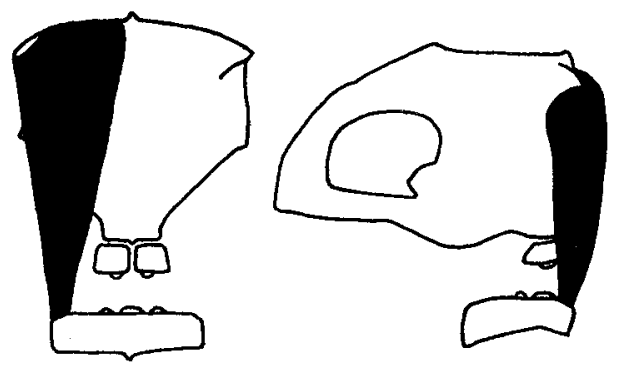

Ba

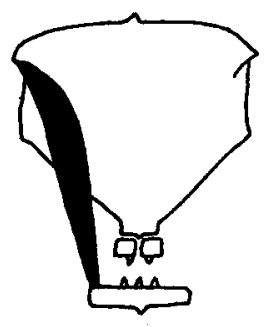

C

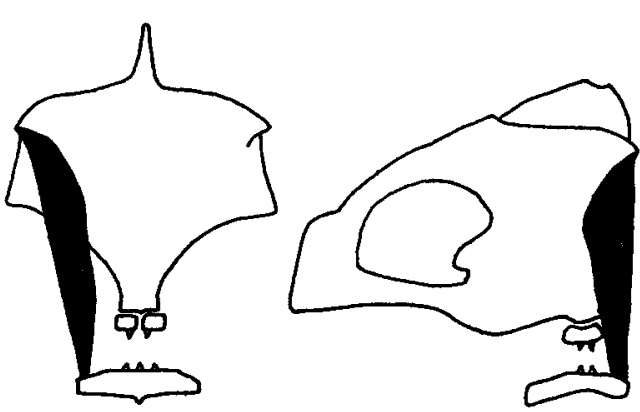

PC
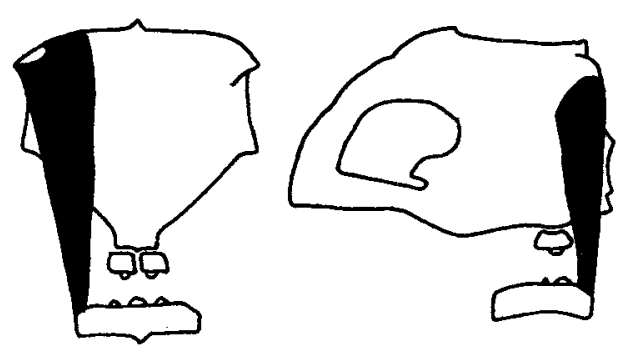

$\mathrm{Bb}$
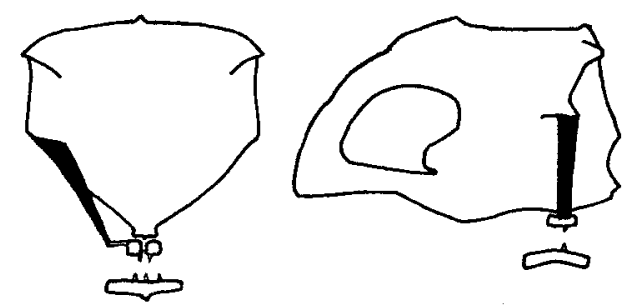

D

Fig. 8. Diagrammatic figures of posterior and lateral views of each type of levator posterior. Concerning posterior view, right levator posterior eliminated. Symbols are same as in Figs. 1, 3 and 4 . 
posterior to the adductor operculi so far as the author can grasp from figures of Liem (1973) and Liem and Osse (1975). It never extends upward. Haplochromis burtoni, a generalized african cichlid fish, has a site of insertion only on the fourth epibranchial. On the other hand, in the mollusc-eating species which demand a powerful adduction of the pharyngeal bones, it is subdivided into two heads. The anterolateral head has the original insertion on the fourth epibranchial, whereas the posteromedial one inserts the muscular process of the lower pharyngeal bone (Liem, 1973; Liem and Osse, 1975).

The following type distinction about the levator posterior of labrid fishes can be made according to the variety of origin and existence of the supraoccipital crest. It serves as a site of insertion of the epaxial muscles in generalized percoid fishes and seems to be concerned with deepening of the body (Fig. 8).

Type PA:

Medial muscle fibers of the levator posterior originate from a surface of the supraoccipital crest which is developed.

Type PB:

It originates from a circumference of the epiotic process. In some species mediomost muscle fibers reach the supraoccipital. The supraoccipital crest is developed.

Type PC:

It originates mainly from a ventral part of the epiotic process. The supraoccipital crest is relatively developed.

Type Ba:

Medial muscle fibers originate from a basal part of the supraoccipital crest and there is scarcely any hiatus between it and the mediomost muscle fibers. The supraoccipital crest is only weakly developed.

Type Bb:

Medial muscle fibers of it originate from the vicinity of sutural line of the epiotic and the supraoccipital at the posterodorsal part of the neurocranium. A hiatus between them can be clearly recognized. The supraoccipital crest is only weakly developed.

Type C:

It originates mainly from a ventral part of the epiotic process. The mediomost muscle fibers never depart from a circumference of this process. The supraoccipital crest is only weakly developed.

Type D:

Even the epiotic process is excluded from a site of origin. It originates from behind the intercalar-pterotic region, i.e. just posterior to the adductor operculi. The supraoccipital crest is only weakly developed.

Now let us try to compare each type with its feeding habit (Table 1). It demonstrates that species included in Type PA feed mainly on tough preys like molluscs and echinoids, those in Type $\mathrm{PB}$ and Type Ba feed on crabs and shrimps, those in Type PG and Type $\mathrm{C}$ feed on amphipods and copepods and those in Type D feed 
Table 1. List of labrid fishes examined on the fourth levator externus and levator posterior. They are distinguished in 7 types according to the developing state of levator posterior. Numbers and body length of specimens studied on intestinal tract contents by the author are put in parentheses in columns. Roman numerals put in the parentheses in columns of intestinal tract contents show the following references: (I) Hashimoto (1974), (II) Hiatt and Strasburg (1960), (III) Hobson (1974) and (IV) examined by the present author.

Abbreviation: AM, amphipods; BI, bivalves; CA, crabs; CO, copepods; GP, coral polyps; CR, crustaceans; EC, echinoids; FE, fish eggs; FO, foraminiferans; FI, fishes; FS, fish scales; IS, isopods; MO, molluscs; PL, polychaetes; SH, shrimps; SN, snails; SP, sponges; ST, stomatopods; LS, large specimens; SS, small specimens;

\begin{tabular}{|c|c|c|c|}
\hline Species & Number & B.L. $(\mathrm{cm})$ & intestinal tract contents \\
\hline \multicolumn{4}{|l|}{ Type PA } \\
\hline Choerodon azurio & $1(1)$ & $12.3(12.3)$ & $\mathrm{BI}, \mathrm{SH}, \mathrm{CA}, \mathrm{EC}(\mathrm{IV})$ \\
\hline C. anchorago & $1(1)$ & $22.6(22.6)$ & $\mathrm{SN}, \mathrm{BI}, \mathrm{CA}(\mathrm{IV})$ \\
\hline zamboangae & $1(1)$ & $23.4(23.4)$ & BI, SN, CA (IV) \\
\hline C. $\quad$ robustus & $2(2)$ & $23.7-24.3\left({ }^{\prime \prime}\right)$ & $\mathrm{SH}, \mathrm{ST}, \mathrm{CA}, \mathrm{SN}(\mathrm{IV})$ \\
\hline Lienardella fasciatus & $1(1)$ & $17.1(17.1)$ & $\mathrm{EC}, \mathrm{SN}, \mathrm{CA}(\mathrm{IV})$ \\
\hline Bodianus perditio & 1 & 19.9 & $\mathrm{SH}, \mathrm{CA}, \mathrm{EC}(\mathrm{I})$ \\
\hline B. loxozonus & 1 & 22.8 & $\mathrm{EC}, \mathrm{SN}, \mathrm{SH}, \mathrm{CA}(\mathrm{I})$ \\
\hline Cheilio inermis & 1 & 15.8 & $\mathrm{SP}(\mathrm{I})$ \\
\hline Macropharyngodon meleagris & 4 & $8.1-10.0$ & $\begin{array}{l}\text { CP(with bony element) (I) } \\
\text { SN, FO (II) }\end{array}$ \\
\hline Halichoeres trimaculatus & 3 & $5.5-9.4$ & $\begin{array}{l}\text { SN, SH, GA, CO (I) } \\
\text { GA, SH (II) }\end{array}$ \\
\hline centiquadrus & $2(2)$ & $21.3-21.9\left(^{\prime \prime}\right)$ & SN, BI, CA, EG (IV) \\
\hline poecilopterus & $19(10)$ & $\begin{array}{l}8.3-17.1 \\
(8.3-16.1)\end{array}$ & $\begin{array}{l}\text { LS: SN, BI, SH, CA } \\
\text { SS: AM, small CR (IV) }\end{array}$ \\
\hline Coris gaimardi & 1 & 14.3 & $\begin{array}{l}\mathrm{BI}, \mathrm{SN}(\mathrm{II}) \\
\mathrm{MO}, \mathrm{EC}(\mathrm{III})\end{array}$ \\
\hline \multicolumn{4}{|l|}{ Type PB } \\
\hline Bodianus diana & $\mathrm{I}(1)$ & $14.1(14.1)$ & $\begin{array}{l}\text { SH, GA, CP(with b.e.) (I) } \\
\text { ST, SH (IV) }\end{array}$ \\
\hline B. $\quad$ oxycephalus & $2(2)$ & $24.1-28.2\left({ }^{\prime \prime}\right)$ & $\mathrm{CA}, \mathrm{SH}, \mathrm{MO}, \mathrm{EG}(\mathrm{IV})$ \\
\hline Pteragogus flagellifera & $16(8)$ & $\begin{array}{l}7.5-13.2 \\
(7.9-11.9)\end{array}$ & $\mathrm{MO}, \mathrm{CR}, \mathrm{EG}, \mathrm{FO}, \mathrm{FI}(\mathrm{IV})$ \\
\hline Pseudolabrus japonicus & 2 & $15.6-16.2$ & SP, GP, small CR (I) \\
\hline Halichoeres margaritaceus & 1 & 8.9 & $\mathrm{SH}, \mathrm{FO}, \mathrm{PL}(\mathrm{II})$ \\
\hline H. $\quad$ tenuispinnis & $12(7)$ & $\begin{array}{l}6.6-15.2 \\
(6.9-10.2)\end{array}$ & $\begin{array}{l}\text { IS, AM (I) } \\
\text { AM, SH, CA (IV) }\end{array}$ \\
\hline Coris variegata & $5(5)$ & $7.3-11.0\left(^{\prime \prime}\right)$ & $\begin{array}{l}\text { LS: MO, GR } \\
\text { SS: CR (IV) }\end{array}$ \\
\hline Cheilinus chlorurus & 1 & 12.6 & $\begin{array}{l}\text { SH, CA, ST, SN (I) } \\
\text { SN, SH (II) }\end{array}$ \\
\hline C. $\quad$ bimaculatus & 1 & 7.5 & $\mathrm{SH}, \mathrm{CA}, \mathrm{CO}(\mathrm{I})$ \\
\hline Epibulus insidiator & 1 & 21.7 & $\begin{array}{l}\text { SH, CA (I) } \\
\text { SH, CA (II) }\end{array}$ \\
\hline Type PC & & & \\
\hline Pseudolabrus gracilis & $8(8)$ & $8.5-11.8^{\prime}\left(^{\prime \prime}\right)$ & AM, small CR, PL (IV) \\
\hline Halichoeres marginatus & 2 & $6.4-9.8$ & $\mathrm{IS}, \mathrm{CO}, \mathrm{PL}$ (II) \\
\hline Anampses meleagrides & 1 & 11.0 & PL (I) \\
\hline A. $\quad$ caeruleopunctatus & 2 & $6.3-13.0$ & $\mathrm{AM}, \mathrm{CP}, \mathrm{SH}(\mathrm{I})$ \\
\hline
\end{tabular}


Table 1. (continued)

\begin{tabular}{|c|c|c|c|}
\hline Species & Number & B.L. $(\mathrm{cm})$ & intestinal tract contents \\
\hline Coris awayai & 1 & 12.7 & AM, small CR (I) \\
\hline Hologymnouss semidiscus & 1 & 27.3 & $\mathrm{SH}(\mathrm{I})$ \\
\hline \multicolumn{4}{|l|}{ Type Ba } \\
\hline Thalassoma lunare & 7 & $9.1-17.5$ & $\mathrm{CA}, \mathrm{EC}, \mathrm{SH}(\mathrm{I})$ \\
\hline T. $\quad$ lutescens & 2 & $9.3-11.0$ & $\begin{array}{l}\mathrm{CA}, \mathrm{SH}, \mathrm{SN}(\mathrm{I}) \\
\text { SH, CA, SN (II) }\end{array}$ \\
\hline \multicolumn{4}{|l|}{ Type Bb } \\
\hline Thalassoma cupido & 3 & $7.9-8.8$ & IS, AM, SH (I) \\
\hline T. $\quad$ hardwicke & 4 & $6.8-14.3$ & $\mathrm{CO}, \mathrm{EC}(\mathrm{I})$ \\
\hline T. quinquevittata & 1 & 8.1 & $\mathrm{CA}, \mathrm{FI}, \mathrm{SH}(\mathrm{II})$ \\
\hline Gomphosus varius & 1 & 11.0 & $\begin{array}{l}\text { SH, GA (I) } \\
\text { SH, CA (II) } \\
\text { CR (III) }\end{array}$ \\
\hline \multicolumn{4}{|l|}{ Type C } \\
\hline Thalassoma amblycephala & 3 & $7.2-10.2$ & $\mathrm{CO}(\mathrm{I})$ \\
\hline Hemigymnus melapterus & 1 & 19.5 & $\begin{array}{l}\text { SH, CA (I) } \\
\text { small SN, CR (II) }\end{array}$ \\
\hline fasciatus & 1 & 21.2 & $\mathrm{AM}, \mathrm{SH}, \mathrm{CA}, \mathrm{SN}(\mathrm{I})$ \\
\hline Stethojulis bandanensis & 1 & 7.4 & $\begin{array}{l}\text { CO, AM, CP(with b.e.) (I) } \\
\text { CO, PL, IS (II) }\end{array}$ \\
\hline interrupta & 1 & 6.5 & AM, small CR (I) \\
\hline Cirrhilabrus cyanopleura & $5(5)$ & $8.4-10.2\left(^{\prime \prime}\right)$ & $\begin{array}{l}\mathrm{CO}(\mathrm{I}) \\
\mathrm{CO}, \text { small CR, FE (IV) }\end{array}$ \\
\hline \multicolumn{4}{|l|}{ Type D } \\
\hline Labropsis manabei & $3(3)$ & $5.4-12.4\left({ }^{\prime \prime}\right)$ & $\begin{array}{l}\mathrm{CP} \\
\mathrm{CP}(\mathrm{I})\end{array}$ \\
\hline Labrichthys unilineata & $4(4)$ & $5.8-8.0\left({ }^{\prime \prime}\right)$ & $\mathrm{CP}, \mathrm{CO}(\mathrm{IV})$ \\
\hline Labroides dimidialus & 9 & $5.2-8.3$ & $\begin{array}{l}\text { IS?, FS, CO (I) } \\
\text { CO (II) }\end{array}$ \\
\hline
\end{tabular}

on coral polyps and ectoparasitic copepods and isopods. The toughness of the food of species in Type $\mathrm{Bb}$ can be considered as intermediate between those of Types $\mathrm{PB}$ and $\mathrm{Ba}$ and Types PG and C. It becomes clear that species with well developed levator posterior feed on tough preys which demand hard biting to crush. The weaker it becomes, the softer the prey changes. Since in labrid fishes, however, there is a close relation between development of the levator posterior and feeding habit it is certain that in addition to three specializations in cichlid fishes, the levator posterior performs an important function in the mechanism of the pharyngeal bones. It is conceivable that this specialization imposes more importance and independence as a feeding complex on the pharyngeal jaw structure in labrid fishes than in cichlid fishes. This point of view may support that in labrid fishes the lower and upper jaw structures are not so correspondent with feeding habit as in cichlid fishes.

Besides above-mentioned characters, both labrid and cichlid fishes show the following common specializations:

In labrid fishes, species which exhibit a well developed levator posterior have a 
well developed lower pharyngeal bone and molar-like teeth. On the contrary, species which exhibit a weakly developed one have a only weakly developed lower pharyngeal bone and many small conical teeth. Cichlid fishes also show considerable specializations with the dentition of the pharyngeal bones and they correspond to their feeding habits. In mollusc-eating species, the enlarged molar-like teeth develop (Fryer and Iles, 1972; Greenwood, 1974).

The retractor pharyngeus superior of a generalized percoid, Pristolepis fasciatus, originates from the first three vertebrae. The movement of the pharyngeal bones transports food into the esophagus and food preparation (or mastication) by them does not take place in Pristolepis (Liem, 1973). The author infers that the development of pharyngeal jaw structure in labrid fishes is related to the functional change of this structure from only transporting food as in Pristolepis to food preparation as in cichlid fishes. Their lower pharyngeal bones are suturally united and retractor pharyngeus superior originates from the first four vertebrae (Liem, 1973).

It seems that in hard-biting cichlid fishes, the attaching site of the pharyngohyoideus to the lower pharyngeal bone shifts posteriorly and becomes tendinous at the surface of the pharyngocleithralis externus (Liem, 1973). This pattern also can be seen in every species of labrid fishes.

The postpharyngeal ligament occurs in some species requiring a powerful bite during mastication in cichlid fishes too. This ligament, in cooperation with some muscles, may fix the lower pharyngeal bone in such a way as to simulate a joint (Liem, 1973).

As with the levator posterior, the retractor pharyngeus superior, pharyngohyoideus and postpharyngeal ligament develop better in labrid fishes than in cichled fishes. In the former, they show the same pattern as that of the species feeding on tough prey in the latter or a further developed pattern. This fact means that the pharyngeal jaw structure of labrid fishes becomes more independent as a feeding structure than that of cichlid fishes.

Then, the origin of such a morphological pattern in labrid fishes should be speculated. This problem seems to lie in the environment in which labrid fishes differentiated and underwent the adaptive radiation. In this case, the environment indicates coral reefs where numerous species inhabit presently. Modern coral reefs were established in the Eocene, about 50 million years ago, with genera of hermatypic corals unknown in older rocks and many of these have survived until today (Newell, 1971). Of the fishes observed along coral reefs, extraordinarily abundant species belong to the acanthopterygian (Smith and Tyler, 1972; Hobson, 1974). Historically, members of the perciformes first appeared at the very top of the Cretaceous, but by the Lower Eocene a great range of perciform types has appeared and most of the living groups are already differentiated (Patterson, 1964). The history of acanthopterygian fishes seems to be at least coextensive with the history of modern coralalgal reefs (Smith and Tyler, 1972). And so it is logical to guess that the adaptive radiation of labrid fishes occurred simultaneously with that of other acanthopterygians living in coral reefs. If this hypothesis is reliable, one can postulate that the com- 
petition for ecological niche, i.e. feeding and habitat interrelationships with other fishes, became severer. Labrid fishes seem to have avoided competitions with other members of the acanthopterygian having a paired, independent fifth ceratobranchials and differentiated into exploitation of the niche by means of a fused lower pharyngeal bone. Strong selection pressure must have been brought to the pharyngeal jaw structure. This appears to explain both extreme muscle patterns of the levator posterior in labrid fishes. One is the same as shown by hard-biting cichlid fishes and the other is the same as shown by Pristolepis fasciatus, a generalized percoid. Also there is no example in labrid fishes like Cichla ocellaris in cichlid fishes which may be considered intermediate between the primitive state as found in generalized percoid fishes and the derived state in more advanced cichlid fishes (Liem, 1973). Intermediate pattern probably became extinct under strong selection pressure.

The supraoccipital crest (spine) generally provides a firm origin for the epaxial muscles. The deepening of the body is related to height of the supraoccipital crest in characinoid fishes (Gregory and Conrad, 1938; Alexander, 1964). According to Patterson (1964), in generalized percoid, the body has become shorter, deeper and more laterally compressed in relation to manoeuvrability and a high supraocciptal crest in acanthopterygian is therefore a consequence of the increased depth of the trunk. Roughly speaking, in labrid fishes a similar relation between depth of the body and size of the supraoccipital crest seems to exist. The supraoccipital crest, however, provides a site of origin for the levator posterior and so it is important as a structure for feeding in species included in Type PA. On the basis of the abovementioned facts, the author guesses that body of the ancestral labrid fishes was deep

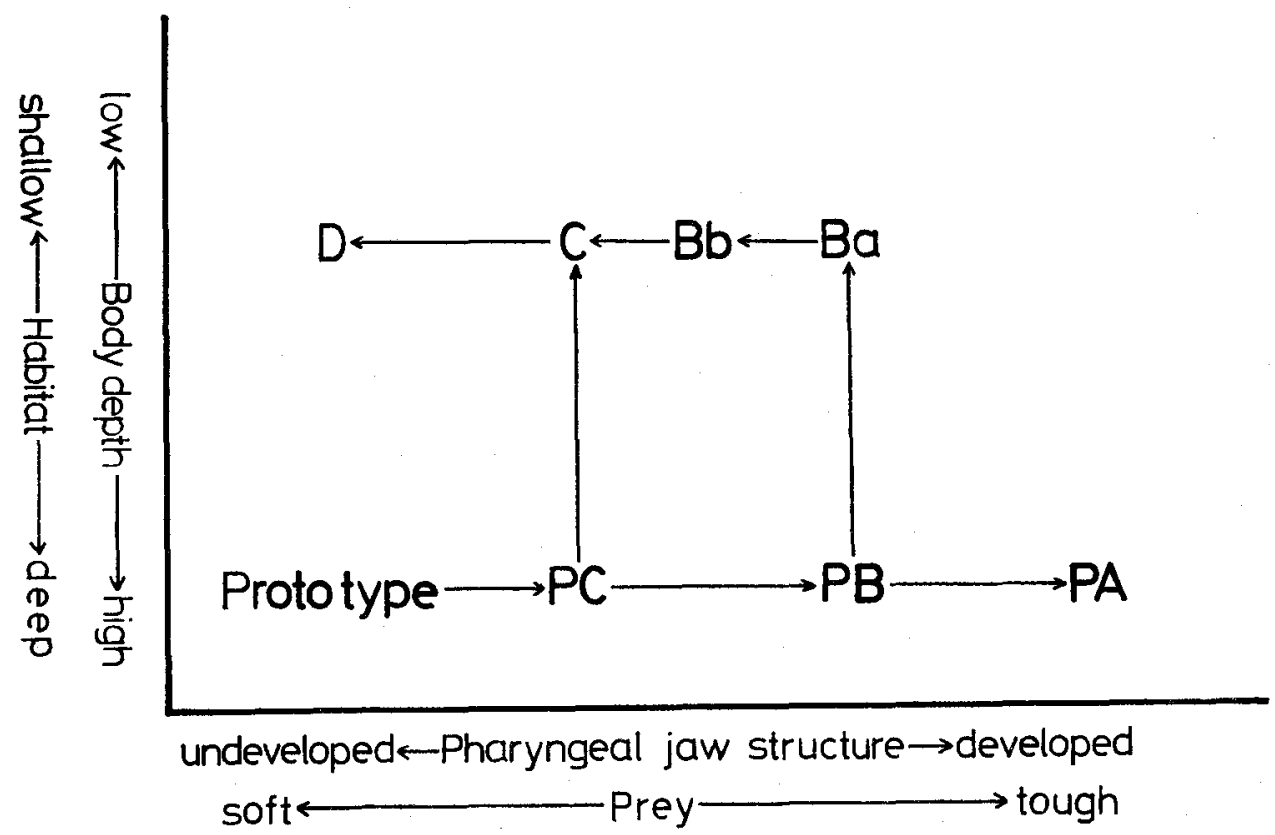

Fig. 9. Mechanical differentiation of pharyngeal jaw structure in labrid fishes. 
and the supraoccipital crest was high. Development of the pharyngeal jaw structure has been like that of Type PG which is also shown in European labrid fishes in the figure of Rognes (1973). Fig. 9 shows type differentiation of the pharyngeal jaw structure in labrid fishes. Species included in Type PG in Table 1 actually do not have so deep bodies and their supraoccipital crests diminish in size or are modified. They should be considered rather near Type C. Body of the species of subfamily Bodianinae is in general deep (Masuda et al., 1975). Specimens of this subfamily examined are all classified into Types PA and PB. They are usually found in rather deeper waters around rocky areas and scarcely at flats in coral reefs. On the contrary, species of subfamily Corinae have generally small and elongate bodies and inhabit shallow waters (Masuda et al., 1975). They are mainly classified into Types Ba, Bb, C, D and PC. A small and elongate body is advantageous to inhabit coral rich habitats which provide various refuges. Despite many exceptions, it is assumed from the available evidence that there exist certain interrelationships among body depth, habitat and development of the pharyngeal jaw structure.

\section{Acknowledgements}

I am very grateful to Professor Tamotsu Iwai and Mr. Chuichi Araga of Kyoto University for their encouragements and critical readings of the manuscript. My special thanks are also due to Messrs. Mutsumi Nishida and Ryuzo Fukao of our laboratory and Mr. Tetsuo Yoshino, University of Ryukyus, for their helpful advice and supports throughout the course of this study. Thanks are also due to the following persons for providing materials studied: Mr. Tetsuo Kuwamura, Seto Marine Biological Laboratory, Kyoto Univresity, Mr. Tetsuji Nakabo, Faculty of Agriculture, Kyoto University, Mr. Jun Hashimoto of Japan Marine Science and Technology Center and Mr. Kazuhiko Shimada, Facutly of Fisheries, Kagoshima University.

\section{REFERENCES}

Alexander, R. McN. 1964. Adaptation in the skull and cranial muscles of South American characinoid fish. J. Linn. Soc. (Zool.), 45, 160-190.

Bock, W.J. and Ch. R. Shear. 1972. A staining method for gross dissection of vertebrate muscles. Anat. Anz., 130, 222-227.

Fryer, G. and T.D. Iles. 1972. The cichlid fishes of the great lakes of Africa: Their biology and evolution. Oliver and Boyd, Edinburgh, 1-641.

Greenwood, P.H. 1974. The cichlid fishes of the Lake Victoria, East Africa: The biology and evolution of a species flock. Bull. Br. Mus. nat. Hist. (Zool.) Suppl., 6, 1-134.

*Gregory, W.K. and G.M. Conrad. 1938. The phylogeny of the characin fishes. Zoologica, 23, 319360.

Hashimoto, J. 1974. A study of feeding habits of the reef fishes in the Nansei Islands. Master Thesis of Kagoshima University.

Hiatt, R.W. and D.W. Strasburg. 1960. Ecological relationships of the fish fauna on coral reefs of the Marshall Islands. Ecol. Monogr., 30, 65-127.

Hobson, E.S. 1974. Feeding relationships of teleostean fishes on coral reefs in Kona, Hawaii. Fish. Bull., 72, 915-1031.

Liem, K.F. 1973. Evolutionary strategies and morphological innovations: Cichlid pharyngeal 
jaws. Syst. Zool., 22, 425-441.

Liem, K.F. and J.W.M. Osse. 1975. Biological versatility, evolution, and food resource exploitation in African cichlid fishes. Amer. Zool., 15, 427-454.

Masuda, H., C. Araga, and T. Yoshino. 1975. Coastal fishes of southern Japan. Tokai Univ. Press, Tokyo, 1-379.

Newell, N.D. 1971. An outline history of tropical organic reefs. Am. Mus. Novit., (2465), 1-37.

Patterson, C. 1964. A review of Mesozoic acanthopterygian fishes, with special reference to those of the English Chalk. Philos. Trans. Roy. Soc. Lond., Ser. B, Biol. Sci., 247, 213-482.

Randall, J.E. and V.G. Springer. 1973. The monotypic Indo-Pacific labrid fish genera Labrichthys and Diproctacanthus with description of a new related genus, Larabicus. . Proc. Biol. Soc. Wash., 86, 279298.

Rognes, K. 1973. Head skeleton and jaw mechanism in Labrinae (Teleostei: Labridae) from Norwegian waters. Univ. Bergen Arb. Mat.-Naturv. Ser. 1971, 4, 1-149.

Smith, C.L. and J.C. Tyler. 1972. Space resource sharing in a coral reef fish community. In "B.B. Collette and S.A. Earle (eds.), Result of the Tektite program: ecology of coral reef fishes". Los Angeles County Mus., Sci. Bull., 14, 125-170.

Winterbottom, R. 1974. A descriptive synonymy of the striated muscles of the Teleostei. Proc. Acad. Nat. Sci. Philadelphia, 125, 225-317.

(Asterisk marks that to which the author did not gain access)

\section{EXPLANATION OF PLATE I.}

Dorsal view of lower pharyngeal bone of following species.
A. Macropharyngodon meleagris
B. Halichoeres centiquadrus
C. Choerodon anchorago
D. Bodianus perditio
E. Halichoeres margaritaceus
F. Thalassoma quinquevittata
G. Anampses caeruleopunctatus
H. Cirrhilabrus cyanopleura 

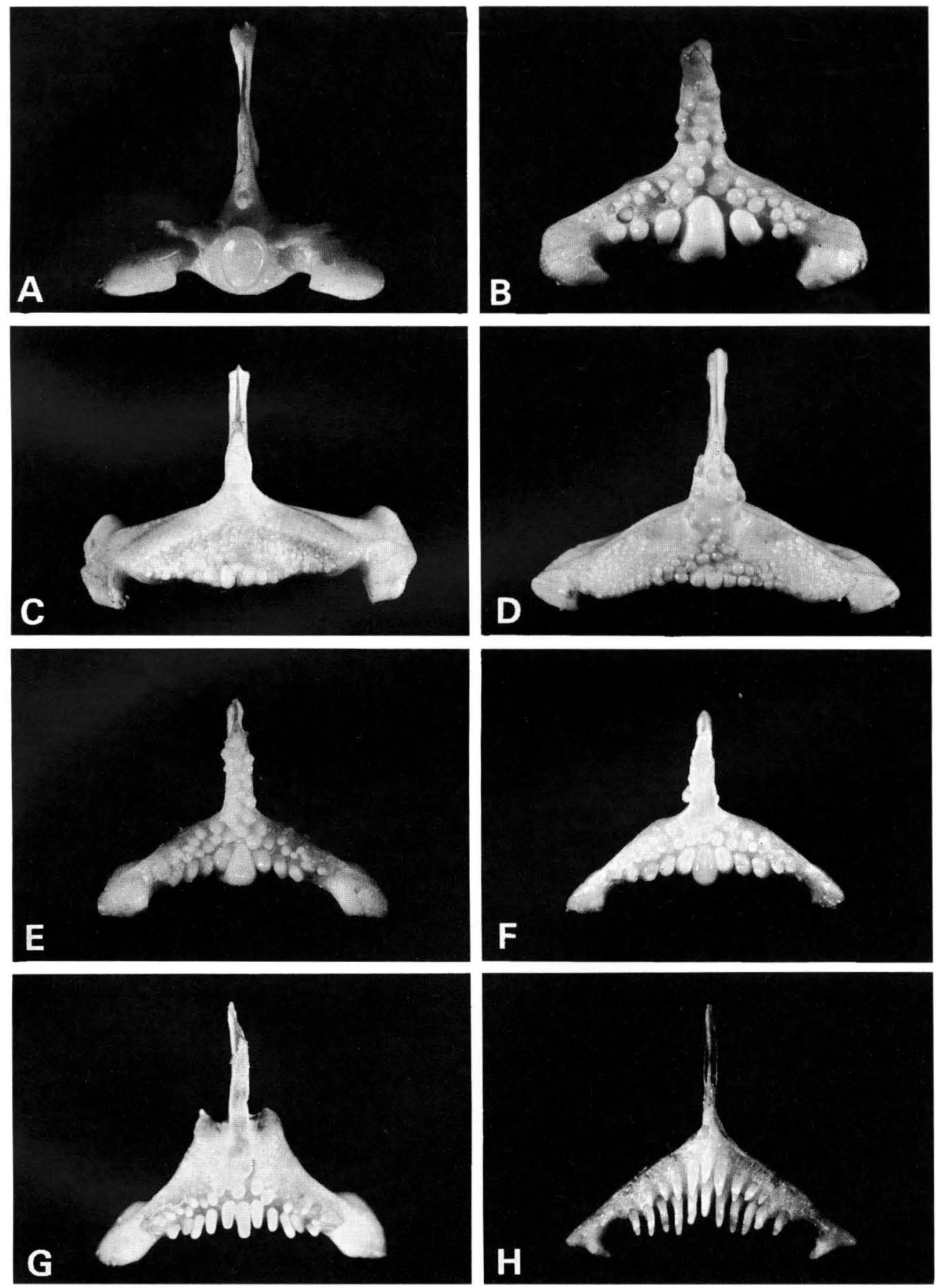

K. YАмаока: Pharyngeal Jaw Structure in Labrid Fish 